\title{
PURIFICATION OF HISTAMINE RECEPTOR (III) CHARACTERIZATION OF RECEPTOR RICH MEMBRANE FRACTION OF SMALL INTESTINAL SMOOTH MUSCLE OF THE CAT
}

\author{
Masaatsu UCHIDA* and Keijiro TAKAGI \\ Department of Chemical Pharmacology, Faculty of Pharmaceutical Sciences, \\ University of Tokyo, Bunkyo-ku, Tokyo 113, Japan
}

Accepted August 30, 1976

\begin{abstract}
Intracellular localization of histamine receptors in small intestinal smooth muscle of the cat was studied by investigating distribution of marker enzymes in the receptor rich fraction. Distribution of membrane markers coincided with that of the radiochemically labeled receptor fraction. Membrane fraction was further purified and it was concluded that the histamine receptor rich fraction is mainly composed of cell membrane. The chemical composition of the fraction lent support to this conclusion.
\end{abstract}

In our previous papers $(1,2)$ we reported data on the fractionation of histanine receptors of small intestinal smooth muscle in the cat. The radioactivity difference were investigated between the muscle labeled with radioactive dibenamine under protection with specific or non-specific drugs and the muscle without protective drugs. The fraction was obtaincd in which specifically labeled histamine receptors were concentrated. The specificity of the fraction was proved by examining the pattern of distribution of radioactivity differences in subcellular fractions of the muscle protected with specific drugs or with non-specific drugs which did not protect histamine receptors pharmacologically but did provide radiochemical protection.

The present work deals with intracellular localization of histamine receptors in relation to distribution of enzymatic activities and the biochemical nature of histamine receptor rich fraction is discussed.

\section{MATERIALS AND METHODS}

${ }^{14} \mathrm{C}$-Labeled dibenamine was synthesized as reported previously (1). Labeling of the longitudinal smooth muscle of cat small intestine was performed according to Procedure II of a previous paper (1). Radioactivity difference was examined between the muscle labeled with hot dibenamine alone and that labeled with hot dibenamine in the presence of diphenhydramine $\left(1 \times 10^{-6} \mathrm{M}\right)$, which could protect histamine receptors from dibenamine ( $4 \times 10^{-6} \mathrm{M}, 20 \mathrm{~min}$ ). Labeled muscle was homogenized in the same manner as was reported previously (2). To obtain a more purified receptor rich fraction, the procedure for preparation of membrane fraction was modified as follows: by centrifugation at $15,000 \times \mathrm{g}$ for

* Present Address: Department of Molecular Pharmacology, Meiji College of Pharmacy, Setagayaku, Tokyo 154, Japan. 
$30 \mathrm{~min}$, the supernatant of muscle homogenates [in $0.2 \mathrm{M}$ sucrose solution $(10 \mathrm{mM}$ TrisEDTA buffer, pH 7.4)] was layered on the top of the sucrose density gradient $(\mathrm{d}=1.10-1.22)$ and centifuged at $105,000 \times \mathrm{g}$ for $2 \mathrm{hr}$ (SW 40 roter in a Hitachi Model 65P ultracentrifuge). Protein content of the collected fraction was monitored by following the absorbance at $280 \mathrm{~nm}$. The peaks were diluted to bring the sucrose concentration to ca. 5.6 with $0.02 \mathrm{M}$ Tris-Inaleate buffer ( $\mathrm{pH}$ 7.4) and centrifuged down at $105,000 \times \mathrm{g}$ for $40 \mathrm{~min}$ to remove sucrose. The membrane fraction thus obtained was resuspended in $0.6 \mathrm{M} \mathrm{KCl}(10 \mathrm{mM}$ Trismaleate buffer, $\mathrm{pH}$ 7.6) for $1 \mathrm{hr}$ under gentle stirring to dissolve contaminated actomyosin and then centrifuged down at $75,000 \times \mathrm{g}$ for $40 \mathrm{~min}$.

For individually more purified fractions (Table 2-below), the histamine receptor fraction was obtained according to the above procedure. Purified nuclei were prepared according to the method of Chauveau et al. (3) from a homogenate in hypertonic sucrose containing $3 \mathrm{mM} \mathrm{CaCl}_{2}$. Mitochondria were isolated by the method of Sone and Hagihara (4). Actomyosin of the smooth muscle was extracted according to the method of Csapo (5). For enzymatic assay and chemical analysis, each fraction was prepared from nonlabeled longitudinal smooth muscle of the small intestine of the cat and thoroughly washed with $0.02 \mathrm{M}$ Tris-malcate buffer ( $\mathrm{pH} \mathrm{7.4)}$ ) before the assay.

Activity of marker enzymes was measured as follows; succinic dehydrogenase (6), cytochrome c oxidase (7), monoamine oxidase (8), NADPH-cytochrome c reductase (9), glucose-6-phosphatase (10), acid phosphatase (pH 5.5) (11), 5'-nucleotidase (12), urate oxidase (13), true and pseudo choline esterases (14) and adenosine triphosphatases; $\mathrm{Mg}^{2+}$ dependent ATPase, $\mathrm{Na}^{+}-, \mathrm{K}_{-}^{+}, \mathrm{Mg}^{2+}$-dependent ATPase and $\mathrm{Ca}^{2+}{ }_{-}, \mathrm{Mg}^{2+}$ - dependent ATPase (15).

Protein was measured by the microbiuret reaction (16) using bovine serum albumin as the standard. Lipids were extracted according to the method of Folch (17) and organic phosphate was determined according to the method of Fiske and Subbarow (18) after digestion with perchloric acid. Phospholipid content was measured by the method of Chen et al. (19). A factor of 25 was used to convert $\mu \mathrm{g}$ phosphorus to $\mu g$ phospholipid. Extracted phospholipids were separated by thin-layer chromatography $(20,21)$.

\section{RESULTS}

Táble 1 shows distribution of radioactivity differences and 5 -nucleotidase activity in subcellular fractions of the smooth muscle. Both values were not specific activities but rather percentages of the distribution. These two values werc dispersed in all fractions although they were largest in $50,000 \times \mathrm{g}$ ppt fractions.

Figure 1 shows the profile at $280 \mathrm{nin}$ of sucrose gradient fractionation of the supernatant obtained at $15,000 \times$ g centrifugation. The enzymatic activities and radioactivity differences of the first peak are listed in the column of 'membrane fraction' in Table 2.

Table 2 shows the specific activities of various marker enzymes of intracellular components in crude fractions (above) and individually more purified fractions (below). Each purifed fraction had its own specific enzymatic activities or chemical composition. The 
TABLE 1. Distribution of radioactivity difference and 5 -nucleotidase activity

\begin{tabular}{rcc}
\hline & $\begin{array}{l}\text { distribution of } \\
\text { radioactivity } \\
\text { difference }(\%)\end{array}$ & $\begin{array}{l}5^{\prime} \text {-nucleotidase } \\
\text { activity }(\%)\end{array}$ \\
$1,000 \times \mathrm{g} \mathrm{ppt}$ & $18 \pm 2$ & $17.6 \pm 1.4$ \\
$10,000 \times \mathrm{g} \mathrm{ppt}$ & $12 \pm 1$ & $8.7 \pm 1.2$ \\
$50,000 \times \mathrm{g} \mathrm{ppt}$ & $27 \pm 3$ & $69.1 \pm 5.2$ \\
$105,000 \times \mathrm{g} \mathrm{ppt}$ & $21 \pm 1$ & $16.2 \div 1.8$ \\
supt & $16 \ldots 2$ & $14.1 \div 1.1$ \\
\hline
\end{tabular}

Eight preparations, (Mean S.E.)

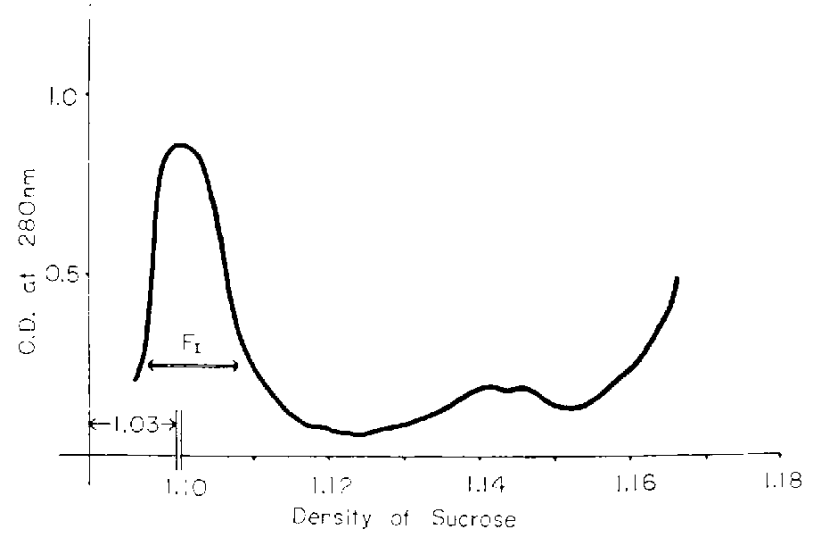

FIG. 1. Sucrose density gradient profile of membrane fraction. Tubes were punctured and the contents displaced from the bottom with a havier sucrose chase solution. The effluent was monitored at $280 \mathrm{~nm}$, The part noted as ' $\mathrm{F}$ ' was collected, washed and used as 'membrane fraction'.

nuclei fraction showed generally recognized protein/DNA ratio [90] and RNA/DNA ratio [0.24]. Mitochondrial markers such as succinic dehydrogenase and cytochrome coxidase were rich in mitochondrial fraction but not in the membrane fraction. Monoamine oxidase, a marker of fragmented mitochondria, was not distributed in the membrane fraction. Ribosomal protein/RNA ratio was near 1. Actomyosin showed superprecipitation under the conditions described by Filo et al. (22). Acid phosphatase, a marker of lysosome, and urate oxidase, that of peroxosome were present only in minute amounts in the membrane fraction. Preliminary assay of UDP-glucosamine-glycosyl transferase, a possible marker of Golgi apparatus, showed no activity in the membrane fraction. NADPH-cytochrome c reductase, also a possible marker of endoplasmic reticulum in some cases, showed poor levels in the membrane fraction. Activity of glucose-6-phosphatase, a marker of endoplasmic reticulum in the liver, was low in all fractions.

Enzymes having high specific activities in the membrane fraction were 5'-nucleotidase, true choline esterase, $\mathrm{Mg}^{2+}$-ATPase, $\mathrm{Na}^{+}, \mathrm{K}^{+}$-ATPase and $\mathrm{Ca}^{2+}$-ATPase. The ratio of butyrylcholine esterase to total acetylcholine estcrase was the criteria for activity of true 


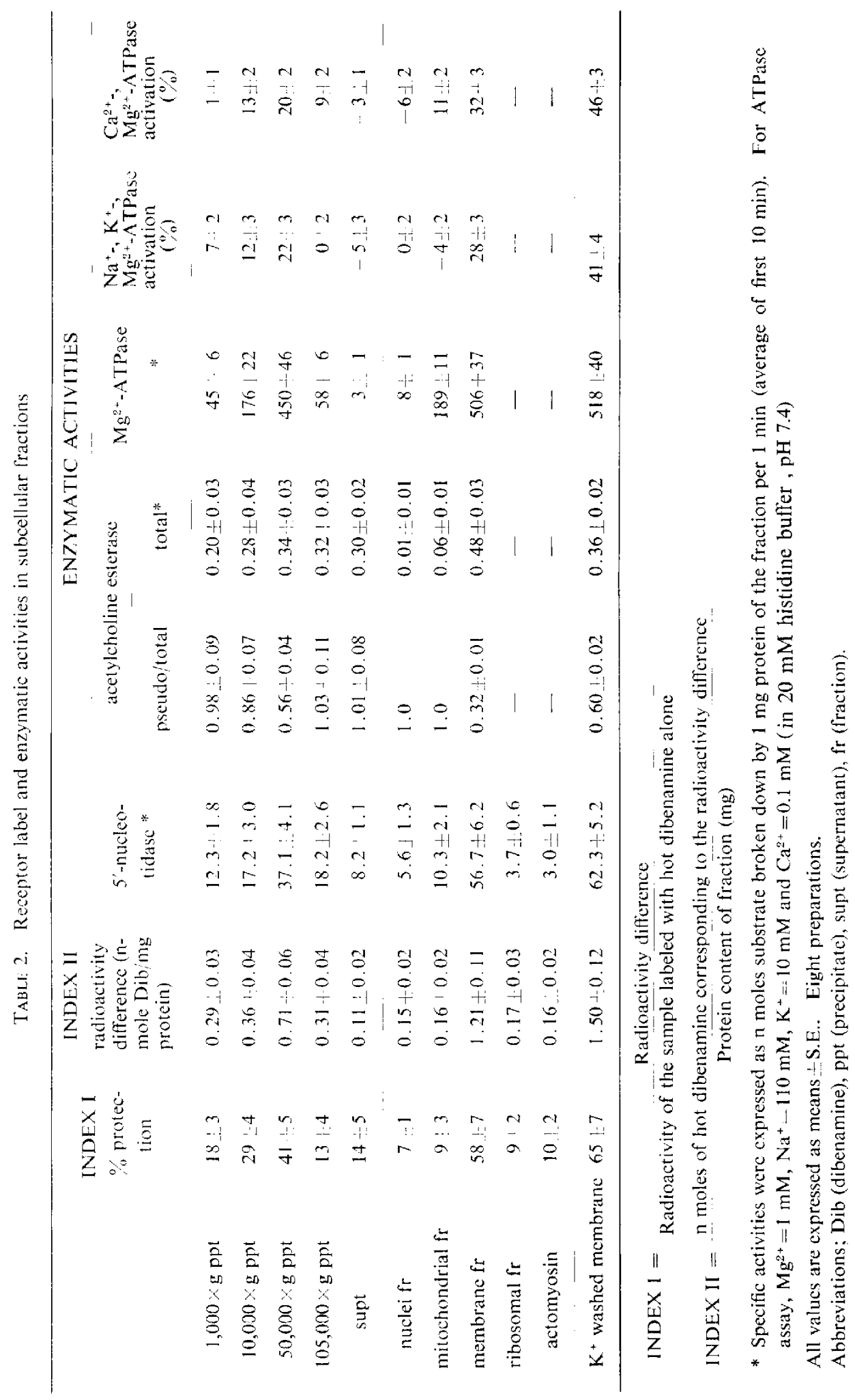


TABLE 3, Chemical composition of receptor rich fraction

\begin{tabular}{lcc}
\hline & $\begin{array}{c}\% \text { distribution } \\
\text { (weight) }\end{array}$ \\
Protein & & 58.7 \\
Total lipids & 30.8 \\
Cholesterol & 6.7 \\
RNA & 2.8 \\
Hexosamine & 0.8 \\
Sialic acid & 0.1 \\
\hline
\end{tabular}

Four preparations

TABLE 4. Phospholipid composition of receptor rich fraction

\begin{tabular}{lc}
\hline & $\begin{array}{c}\text { \% distribution } \\
\text { (weight) }\end{array}$ \\
Phosphatidylcholine & $48.2 \pm 7.0$ \\
Phosphatidylethanolamine & $18.4 \div 4.1$ \\
Sphingomyelin & $12.3 \pm 2.0$ \\
Lysophosphatidylcholine & $10.2 \pm 0.8$ \\
Phosphatidylserine & $7.0 \pm 0.4$ \\
Phosphatidylinositol & trace \\
cholesterol/total phospholipid $=0.91 \pm 0.08$
\end{tabular}

Ten preparations. (Mean_-2 S.E.)

choline estcrase. Their ratio was particularly low in the membrane fraction. This implies high activity of true choline esterase. The ratio of activity in $\mathrm{Na}^{+}(110 \mathrm{mM})$ and $\mathrm{K}^{+}$ $(10 \mathrm{mM})$ containing medium to that in the medium free from monovalent cations, substituted by choline chloride, was used as the criteria of $\mathrm{Na}^{+}-, \mathrm{K}^{+}$-ATPase. This value was highest in the membrane fraction. This ATPase was rich in the membrane fraction. Activation of ATPase with $\mathrm{Na}^{+}$and $\mathrm{K}^{+}$in the membrane fraction was blocked $(80 \%)$ by ouabain $\left(5 \times 10^{-6} \mathrm{M}\right)$. With purification, membrane marker enzymes and radioactivity differences were decreased in fractions other than the membranc fraction, while such were increased in the membrane fraction.

Table 3 shows chemical composition of the membrane fraction. The fraction was composed mainly of protein and phospholipids. Ribosomes were scarcely contaminated as was concluded from the low content of RNA in the membrane fraction. Lipid composition is listed in Table 4 and resembled sarcolemna of skeletal muscles and not sarcoplasmic reticulum (23).

\section{DISCUSSION}

5 -Nucleotidase has been widely used as a plasma membrane marker (12) and a greater part of the activity is found in the membrane fraction. As shown in Table 1, the percent 
distribution of this marker closely paralleled that of radioactivity differences in all fractions, suggesting that the labeled receptor was attached to the membrane. Another marker of plasma membrane in excitable cells is true choline esterase. As the small intestinal muscle of the cat is cholinergically innervated, extrusive localization of this enzyme in receptor fraction indicates that the fraction consisted of fragmented plasma membrane. The localization of ouabain sensitive $\mathrm{Na}^{+}-, \mathrm{K}^{+}$-ATPase also indicates this.

As shown in Table 2, distribution of specific activities of membrane marker enzymes (5'-nucleotidase, acetylcholine esterase, $\mathrm{Na}^{+}-\mathrm{K}^{+}$-ATPase and $\mathrm{Ca}^{2+}$-ATPase) were parallel, in general, to the radioactivity difference (nmoles labeled dibenamine/mg protein) and the degrec of protection (2). Before purification of subcellular fractions, membrane markers and radioactivity differences were found in all fractions but after purification of the particulates, membrane marker enzymes and radiodctivity differences decreased remarkably in fractions other than the membrane fraction. The greater part of these radioactivity differences seened to be associated with the membrane. Thus modifications were made in the course of membrane purification. Membrane fraction was obtained in the previous paper (2) by means of sucrose density gradient fractionation of $50,000 \times \mathrm{g}$ precipitate of muscle homogenates. Two broad pcaks were obtained and one was much larger than the other. The two peaks overlapped and enzymatic activities, chemical composition and radioactivity differences were much the same in both fractions. One of the peaks may be a denatured membrane moiety as the result of the long incubation of the muscle during the labeling procedure. We again attempted to purify the plasma membrane fraction by sucrose density gradient separation. Instead of $50,000 \mathrm{ag}$ sediment, $15,000 \times \mathrm{g}$ supernatant of the muscle homogenate was direcly applied onto the gradient. The fraction which has once been sedimented tends to show a single band in the gradient. The band contains several kinds of marker enzymes. This phenomenon is the result of aggregation of intracellular components due to centrifugal force (Takano, personal communication., 24).

To avoid this aggregation, the supernatant was used for application on the gradient and $0.05 \mathrm{mM}$ LDTA was added to the medium. EDTA was not added in the former experiments $(1,2)$ when the purpose was to study $\mathrm{Ca}^{2+}$ and $\mathrm{Mg}^{2+}$ movements in the membrane. The time of uluracentrifugation and g-value was increased to obtain more purified fractions. The first peak $(\mathrm{d}=1.10)$ was sharp and did not overlap the others. This fraction could be defined as mainly composed of plasma membrane from the results of chemical and enzymatic analysis. This fraction had the largest radioactivity difference, which represents labeled histamine recentors $(1,2)$. It is not excluded, however, that membranes originated from caveolae and endoplasmic reticulum may be contaminated in this fraction. Appropriate biochenical markers of caveolae have not been found and the marker enzymes of endoplasmic reticulum in smooth muscles have not been established. Contamination of other components of the cell proved to be small. Among the smooth muscles, cell membranes of uterine smooth muscles were reported to be isolated by similar nethods $(24,25)$. The membrane fraction was washed with $\mathrm{KCl}$ solution in order to remove contaminated actomyosin. $\mathrm{KCl}$ treatment increased radioactivity differences and activities of marker enzymes of cell membrane and 
consequently purity of the receptor rich fraction as plasma membrane.

Labeled dibenamine itself, however, is non-specific in a chemical sense and radioactivity was found in all of the subcellular fractions in these experiments as was suggested in the case of $\alpha$-adrenergic receptor labeling $(26,27)$. Radioactivity difference was, however, localized mainly in the cell membrane.

These results confirmed that histamine receptors in the small intestinal smooth muscle of the cat are located on the cell membrane.

\section{REFERENCES}

1) TAKAGI, K. AND UchidA, M.: Japan. J. Pharmacol. 20, 272 (1970)

2) UChidA, M. AND TAKaGi, K.: Japan. J. Pharmacol. 23, 337 (1973)

3) Cinauveau, J., Moule, Y. And Roliller, C.: Expl Cell Res. 11, 317 (1956)

4) Sone, N. And Hagihara, B.: J. Biochem. 60, 622 (1966)

5) Csapo, A.: Nature 162, 218 (1948)

6) Aldoidge, W.N.: Biochem. J. 73, 270 (1959)

7) Cooperstein, S.J. ANd Lazarow, A : $J$. hiol. Chem. 189, 665 (1951)

8) Schnaitman, C. and Grefnawalt, J.W.: J. cell Biol. 38, 158 (1968)

9) Phillips, A.H. and Langdon, R.G.: J. biol. Chem. 237, 2652 (1962)

10) Hubscher, G. AND West, G.R.: Nature 205, 799 (1965)

11) Ostrowski, W. And Tsugita, T.: Archs Biochem. Biophys. 94, 68 (1961)

12) Evans, W.H.: Biochem. J. 166, 833 (1970)

13) Beanfay, H., Bendall, D.S., Baudhin, D., Wattiaux, R. and de Duve, F.: Biochem. $J .73$, $628(1959)$

14) Aммому, R.: Pfiugers Arch. 233, 486 (1933)

15) Leloir, L.F. And Cardini, C.E.: Methods in Enzymology, Vol. 3, Edited by Colowick, S.P. And Kal'lan, N.O., p. 843, Academic Press, New York (1957)

16) ITZhaki, R.F. And Gill, D.M.: Analyt. Biochem. 9, 401 (1964)

17) Folch, J.: J. biol. Chem. 177, 505 (1949)

18) Fiske, C.H. and Subrarow, Y.: J. hiol. Chem. 66, 375 (1925)

19) Chen, P.S., Toribara, T.Y. and Warier, H.: Analyt. Chem. 28, 1756 (1956)

20) Stahl, E., Schroter, G., Krát, G. and Renz, R.; Pharmazie 11, 633 (1956)

21) Mangold, H.K.: Tinin-layer Chromatography, Edited by Staht, E., p. 363, Springer-Verlag, Berlin, Heidelberg and New York (1969)

22) Filo, R.S., Ruegg, J.C. and Bohr, D.F.: Am. J. Physiol. 205, 1249 (1963)

23) Vandfonburgh, H.H., Sheff, M.F. And ZACKS, S.I.: J. Memb. Biol. 17, I (1974)

24) Kidwai, A.M., Martha, A., Radclitfe, M.A. And Daniel, E.E.: Biochim. Biophys. Acia 233, $538(1971)$

25) Rufeger, U., Tellheim, B. And Kroker, R.: Comp. Biochem. Physiol. 47B, 255 (1974)

26) Yong, M.S. and Marks, G.S.: Biochem. Pharmacol. 18, 1619 (1969)

27) Graham, J.D.P., Ivass, C., Lever, J.D., Mcouiston, R. and Spriggs, T.L.B.: Brit. $J$. Pharmacol. 41, 278 (1971) 